\title{
AKUNTABILITAS PEMERINTAHAN DESA DALAM PENGELOLAAN KEUANGAN DESA DI KABUPATEN SUMBAWA BARAT
}

\section{ACCOUNTABILITY OF VILLAGE GOVERNMENT IN VILLAGE FINANCIAL MANAGEMENT IN WEST SUMBAWA}

\author{
Ilham Zitri* \\ *Ilmu Pemerintahan Universitas Muhammadiyah Mataram \\ Ilhamzitr@gmail.com
}

\begin{abstract}
ABSTARCT
This article discusses the accountability of village financial management in four villages in West Sumbawa District. While the method used is a combination that combines the two methods, the techniques used are interviews, questionnaires and documentation. The results of this study are that the village government still cannot manage village finance in the four villages, namely First, Benete Village, Maluk Subdistrict, Secondly, Maluk Village, Maluk District, Third, Sekongkang Bawah Village, Sekongkang District, and Fourth, Sekongkang Village, Sekongkang Subdistrict. The first problem faced by the village was the limited or limited capacity of the village apparatus in managing village finances or the absence of participation from the village community which made the problem increase.
\end{abstract}

Keywords: accountability, village government, financial management

\begin{abstract}
ABSTRAK
Artikel ini membahas tentang akuntabilitas pengelolaan keuangan desa pada empat desa di Kabupaten Sumbawa Barat. Adapun metode yang digunakan ialah kombinasi yang menggabungkan kedua metode, teknik yang digunakan adalah wawancara, angket dan dokumentasi. Adapun Hasil dari penelitian ini ialah pemerintah desa masih belum bisa mengelola keuangan desa pada Empat desa yaitu Pertama, Desa Benete Kecamatan Maluk, Kedua, Desa Maluk Kecamatan Maluk, Ketiga yaitu Desa Sekongkang Bawah Kecamatan Sekongkang, dan yang Keempat, ialah Desa Sekongkang Atas Kecamatan Sekongkang. Masalah pertama yang dihadapi desa ialah keterbatasan atau terbatasnya kemampuan perangkat desa dalam pengelolaan keuangan desa ataupun tidak adanya partisipasi dari masyarakat desa yang membuat masalah bertambah banyak.
\end{abstract}

Kata kunci : akuntabilitas, pemerintah desa, pengelolaan keuangan

Journal of Governance and Local Politics (JGLP)

ISSN (online): 2684-9992, Vol: 1, Nomor: 1, Mei 2019 


\section{PENDAHULUAN}

Hadirnya otonomi desa diharapkan akan menghasilkan dua manfaat nyata, yang pertama mendorong peningkatan partisipasi masyarakat dalam pembangunan, juga mendorong pemerataan hasil pembangunan (keadilan) dan yang kedua memperbaiki alokasi sumber daya produktif melalui pergeseran peran pengambilan keputusan publik ke tingkat pemerintah yang paling rendah yang memiliki informasi yang paling lengkap. Sedangkan tingkat pemerintah yang paling rendah adalah pemerintah desa. Melihat undang-undang Nomor 6 Tahun 2014 tentang Desa, dijelaskan pada BAB V Pasal 24 bahwa di dalam penyelenggaran pemerintahan desa harus berdasarkan azas akuntabilitas. Azas akuntabilitas yang dimaksud adalah azas yang menentukan bahwa setiap kegiatan dan hasil akhir dari kegiatan penyelenggaran pemerintahan desa harus dapat dipertanggungjawabkan kepada masyarakat desa serta Bupati melalui Camat.

Seperti yang diketahui keuangan desa yang bersumber dari anggaran pendapatan dan belanja negara yang diperuntukan untuk masyarakat. Keuangan desa tidak hanya dari APBN tetapi juga dari APBD dan penghasilan tetap pemerintahan desa yang berasal dari ADD. Pengalokasiannya akan digunakan untuk kepentingan pemerintahan desa dan masyarakat desa. Ironisnya, sumbersumber keuangan desa yang diharapkan bisa menambah pemasukan bagi pemerintahan desa justru banyak diambil oleh pemerintahan daerah. Pemerintahan daerah bersikap ambigu dalam penanganan aset yang ada di desa. Di satu sisi aset tersebut dituntut untuk memberikan pemasukan bagi desa, disisi lain desa yang memiliki aset tersebut (desa) kurang dilibatkan.

Saat ini terdapat kendala umum yang dirasakan oleh beberapa desa terhadap keterbatasan keuangan desa, yaitu APBDes yang tidak seimbang antara peneriman dan pengeluran. Hal tersebut disebabkan setidaknya oleh 4 (Empat) faktor utama (Hudayana, et, $\mathrm{Al}, 2005,2$ ) dalam makalahnya yang berjudul 
peluang pengembangan partisispasi masyarakat melalui kebijakan alokasi dana desa. Pertama, desa memiliki APBDes yang kecil sumber pendapatannya sangat tergantung pada bantuan yang sangat kecil pula. Kedua, kesehteraan masyarakat desa rendah sehinggasusah bagi desa mempunyai pendapatan asli desa (PADes) yabng tinggi. Ketiga, masalah itu diikuti oleh rendahnya dana operasional desa untuk menjalankan pelayanan. Keempat, tidak kalah penting bahwa banyak program pembangunan masuk ke desa, tetapi hanya dikelola oleh dinas. Berdasarkan keempat faktor tersebut, maka penyelenggaran pemerintah desa membutuhkan adanya akuntabilitas dalam pengelolaan keuangan desa (APBDes). Berikut ini tabel anggaran yang seharusnya diterima oleh desa didaerah-daerah sebagai berikut:

Table 1.

Anggaran Yang Didapatkan

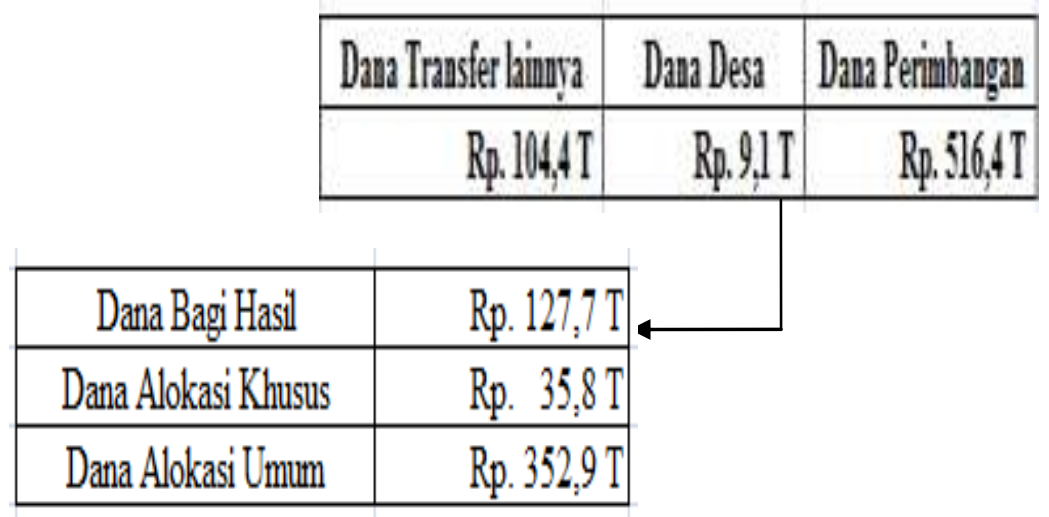

Dari tabel diatas, transfer ke daerah dan dana desa bisa dilihat besaran dana yang diterima darah yang ada di Indonesia, misalnya Dana Perimbangan sebesar Rp 516.4 T, Dana Desa yang berjumlah Rp 9.1 T dan lainya yang bisa dilihat pada data diatas. Menururt Penelitian Faridah 2016 dengan judul penelitian Transparansi dan akuntabilitas pemerintah desa dalam pengelolaan anggaran pendapatan dan belanja Desa Sidogedung batu, hasil dari penelitian ini menunjukan bahwa kepala desa di Desa Sidongdung Batu Kecamatan 
Sangkapuran Kabupatem Gresik telah melaksanakan prinsip-prinsip transparansi dan akuntabilitas pada pengelolaan APBDes tahun anggaran berjalan. Secara umum transparansi dan akuntabilitas di Desa Sidongdung Batu Kecamatan Sangkapuran Kabupatem Gresik sudah berjalan dengan baik, walaupun masih adanya beberapa masalah atau kelemahan yang masih harus diperbaiki oleh pemerintah desa.

Sedangkan pada penelitian Listri dan Sdiputra 2014 dengan judul penelitian Membedah akuntabilitas praktik pengelolaan keuangan Desa Pakraman Kubutambahan Kecamatan Kubutambhan Kabupaten buleleng Bali. Yang menunjukan bahwa (1) proses pengelolaan dan pertanggungjawaban keuangan di Desa Pakraman Kubutambhan tidak melibatkan seluruh krama Desa Pakraman melainkan hanya melalui perwakilan, (2) Akuntabilitas pengelolaan keuangan berlangsung secara konsitem setiap bulan dengan mengungkan sistem akuntansi senderhana (sistem tiga kolom yaitu debet, kredit dan saldo), (3) dengan adanya modal sosial khususnya kepercayaan pengurus Desa Pekraman Kubutambahan menyadari bahwa akuntansi meruapakan instrumen akuntabilitas dan transparansi dalam pengelolaan keuangan di desa pakraman.

Dari beberapa penelitian di atas, berbeda dengan penelitian yang akan dilakukan oleh penulis yaitu melakukan penelitian yang lebih mendalam tentang akuntabilitas pengelolaan keuangan desa. Upaya tersebut ditempuh dengan melibatkan masyarakat desa. Dengan demikian, pengelolaan keuangan desa tidak hanya melibatkan perangkat desa secara sepihak. Sehingga dengan keterlibatan masyarakat secara aktif, maka bisa dinilai pertanggungjawaban perangkat desa dalam pengelolaan keungan desa.

Konsep tentang akuntabilitas secara harfiah dalam bahasa inggris biasa disebut dengan accontability yang diartikan sebagai yang dapat dipertanggungjawaban dalam kata sifat disebut sebagai accontable. Akuntabilitas publik merupakan elemen terpenting dan merupakan tentangan utama yang Journal of Governance and Local Politics (JGLP) ISSN (online): 2684-9992, Vol: 1, Nomor: 1, Mei 2019 
dihadapi pemerintah pusat, daerah maupun pemerintah desa, lagi pula akuntabilitas secara filosofi timbul karena adanya kekuasaan yang berupa mandat/amanah yang diberikan kepada seseorang atau pihak tertentu untuk menjalankan tugasnya dalam rangka mencapai suatu tujuan tertentu dengan menggunakan sarana pendukung yang ada.

Desa sebagai suatu kesatuan masyarakat hukum yang mempunyai kewenangan mengatur dan mengurus kepentingan masyarakatnya sendiri dalam melaksanakan tugasnya memerlukan dana yang memadai. Akuntabilitas akan semakin membaik jika didukung oleh suatu sistem akuntansi yang menghasilkan informasi yang akurat, handal, tetap waktu, serta dapat dipertanggungjawabkan.

Sejalan dengan hal tersebut, akuntabilitas publik merupakan suatu kewajiban bagi agency (sebagai pemegang amanah) untuk mempertanggunjawabkan. Menyajikan, melaporkan, serta mengungkapan segala macam aktivitas kepada principal (sebagai pemberi amanah). Dimana principal tentunya memiliki hak dan kewenangan untuk meminta pertanggungjawaban tersebut (Mardiasmo, 2002).

Dalam hubungan antara principal dan agency (agency theory) kemungkinan akan timbul suatu masalah apabila terdapat informasi alimetri yang menyebabkan agency melakukan tindakan yang menyimpang seperti pemanipulasian data sehingga laporan keuangan terlihat bagus dan tidak menggambarkan kondisi pemerintaha yang seutuhnya. Berdasarkan hal tersebut akuntansi memiliki peranan pwetanggungjawaban (akuntabilitas) dalam hubungan antara principal selaku pemberi amanah dan kekuasaan kepada agency untuk melakukan pekerjaan yang berkaitan dengan kepentingan principal.

Untuk mewujudkan akuntabilitas dengan pemberikan informasi dan pengungkapan (diselosure) aktivitas serta kinerja keuangan pemerintah melalui laporan keuangan kepada seluruh stakeholder diperlukan karena memiliki hak 
publik, yakni hak untuk tahu, hak untuk diberikan informasi dan didengar aspirasinya.

Kelemahn SDM secara langsung atau tidak langsung memengaruhi ketergantungan pemerintah desa terhadap pemerintah daerah dan bantuanbantuan lainya. Kasus yang sering terjadi di desa ialah keterlambatan atau kesalahan pihak desa dalam menyelesaikan tugas-tugas pemerintahan. Misal dalam hal pembangunan, penyusunan APBDes, atau pelaporan kegiatan. Seperti yang telah diuraikan, tidak ada jaminan bahwa perbaikan-perbaikan dalam sistem atau peraturan ini akan menunjang akuntabilitas para pejabat jika pola perilaku para elit pemerintah masih tetap dipengaruhi oleh nilai-nilai lama dalam birokrasi yang masih cenderung tidak demokratis.

\section{METODE PENELITIAN}

Penelitian ini berlokasi pada dua kecamatan yang berada pada Kabupaten Sumbawa Barat, yaitu Kecamatan Maluk dan Kecamatan Sekongkang, dari dua kecamatan ini penulis hanya berfokus pada empat desa yaitu Desa Betete, Desa Maluk pada Kecamatan Maluk dan Desa Sekongkang Bawah, Desa Sekongkang Atas pada Kecamatan Sekongkang Kabupaten Sumbawa Barat.

Fokus penelitian diarahkan pada analisis tentang akuntabilitas pemerintah desa dalam pengelolaan keuangan desa. Melalui analisis tersebut beberapa tujuan yang diharapkan dapat dicapai (1) untuk mengetahui bagaimana pertanggungjawaban pemerintah desa dalam pengelolaan keuangan desa, (2) untuk mengetahui bagaimana partisipasi masyarakat dengan terkait pengelolaan keuangan desa.

Untuk mencapai tujuan analisis tersebut penulis mengunakan metode penelitian Kombinasi (Sugiyono, 2016). Penelitian ini mengunakan teknik pengumpulan data melalui wawancara, analisis dokumentasi dan kuisioner pada masyarakat desa. Kuisioner dilakukan pada 100 renspoden dalam mendukung 
hasil wawancara yang dilakukan, sehingga dapat diambil kesimpulan dalam menjawab pertanyaan penelitian.

Tabel 2.

Karakteristik Responden Berdasarkan Jenis Kelamin Pada Empat Desa Di Kecamatan Maluk Dan Kecamatan Sekongkang

\begin{tabular}{|l|c|c|}
\hline \multicolumn{1}{|c|}{ Jenis Kelamin } & Frekuensi & Persentase (\%) \\
\hline Laki-laki & 62 & $62 \%$ \\
\hline Perempuan & 38 & $38 \%$ \\
\hline \multicolumn{1}{|c|}{ Jumlah } & 100 & $100 \%$ \\
\hline
\end{tabular}

Sumber: diolah penulis

\section{HASIL DAN DISKUSI}

\section{Akuntabilitas Pengelolaan Keuangan Desa Pada Empat Desa Di Kecamatan Maluk Dan Kecamatan Sekongkang}

Akuntabilitas ialah prinsip pertanggungjawaban publik yang berati bahwa proses penganggaran mulai dari perencanaan, penyusunan dan pelaksanaan harus benar-benar dapat dilaporakan dan dipertanggungjawabkan kepada pemerintahan lebih tinggi (DPRD dan bupati) ataupun kepada masyarakat (publik). Kesulitan untuk menuntut pertanggungjawaban pemerintah terhadap kualitas pelaporan pengelolaan keuangan desa disebabkan karena sosok pemerintah itu sendiri tidak tunggal, untuk itu proses atau sistem akuntabilitas bagi lembaga pemerintah atau birokrasi publik yang memadai merupakan prasyarat penting bagi peningkatan kualitas pelaporan yang baik (Kumorotomo, 2013).

Pengelolaan pendapatan dan belanja desa perlu direncanakan dengan sebaik-baiknya menyangkut dasar hukum, program/kagiatan yang akan dilaksanakan, jadwal pelaksanaannya kapan dilakukan, siapa yang akan menjadi pelakunya dalam aktivitas melaksanakan program, berapa besar anggaran yang dibutuhkan atau yang akan digunakan selama kegiatan dan target apa yang akan 
dicapai nantinya dengan pelaksanaan program/kegiatan tersebut. Ditegaskan dalam pengelolaan keuangan desa adanya azas partisipatif, hal ini diartikan perhal pengelolaan keuangan desa yang harus dibuka pada masyayrakat luas untuk peran aktif masyarakat desa, seperti yang saudah diatur dalam undangundang.

Dari beberapa kegunaan keuangan desa, ada beberapa desa yang banyak mengunakan keuangan desa lebih fokus pada program pembangunan desa itu sendiri tanpa melihat perberdayaan masyarakatnya. Hal tersebut dikarenakan dengan majunya pembangunan diharapkan maju pula pertumbuhan manusia, dan tidak kalah pentingnya peran pemerintah pusat dan pemerintah daerah serta masyarakat desa sekitar sangat mempengaruhi pengelolaan keuangan yang ada di desa, agar anggaran bisa dirasakan oleh masyarakat luas, pemerintah desa tidak boleh membuat gap antara perangkat desa dan masyarakat desa.

Setiap pengunaan APBDes wajib untuk dipertanggunagjawabkan, pada prinsipnya semua itu adalah upaya mewujudkan pemerintah yang bersih. Pengelolaan keuangan desa yang tidak terbuka hanya akan menyebabkan kepercayaan masyarakat desa terhadap pemerintah desa semakin menurun. Jika itu terjadi, maka akan mengganggu jalannya pembangunan desa.

Tabel 3.

APBDes pada 4 (Empat) Desa di Kecamatan Maluk dan Kecamatan Sekongkang Kabupaten Sumbawa Barat

\begin{tabular}{|c|c|c|c|c|}
\hline \multirow[t]{2}{*}{ Nama Desa } & \multicolumn{2}{|c|}{ Anggaran Pendapatan } & \multicolumn{2}{|c|}{ Anggaran Belauja } \\
\hline & Sebelum & Setelah & Sebelum & Setelah \\
\hline Desa Benete & Rp. $1,774,140,574,00$ & Rp. $1,536,579,685,00$ & Rp. $1,274,140,574,00$ & Rp. $1,536,579,685,00$ \\
\hline Desa Maluk & Rp. $1,372,612,452,00$ & & Rp. $1,372,612,452,00$ & \\
\hline Desa Sekongkang Bawal & Rp. 1,200,941,042,00 & Rp. 1,329,909,378,00 & Rp. 1,200,941,042,00 & R.p. $1,329,909,378,00$ \\
\hline Desa Sekongkang Atas & Rp. $1,595,452,383,00$ & & Rp. $1,022,712,383,00$ & \\
\hline
\end{tabular}

Journal of Governance and Local Politics (JGLP)

ISSN (online): 2684-9992, Vol: 1, Nomor: 1, Mei 2019 
Sumber: diolah Penulis

Mengelola sistem keuangan bukanlah perkerjaan yang berat namun juga bukan perkerjaan yang mudah. Diperlukan ketelitian, ketangkasan dan keseriusan, apabila sistem keuangan di desa selama ini belum dilaksanakan secara sistematis. Semangat kemandirian desa yang diamanahkan oleh UU No. 6 tahun 2014 tentang desa diharapkan bisa menjadi Motivasi bagi terwujudnya otonomi desa dan yang paling diharapkan desa mampu mengelola keuangan desa.

Pengelolaan keuangan desa tidak dapat dilepaskan dari rangkaian proses perencanaan desa tahunan yang akrab disebut dengan Musyawarah Perencanaan Pembangunan Desa (MusrenbangDes). Keluaran dari Musrenbangdes yaitu dokumen Anggaran Pendapatan dan Belanja Desa. Basis utama penyusunan APBDes yaitu dokumen RPJMDes (Rencana Pembangunan Jangka Menengah Desa) dan RKPDes (Rencana Kegiatan Pembangunan Desa).

Menurut Mardiasmo (2015) mengemukakan bahwa orientasi pembangunan sektor publik adalah untuk menciptakan good governance dimana dasarnya ialah tata kelola pemerintahan yang baik, sedangkan menurut World Bank (Sedarmayanti, 2009) penyelenggaran pembangunan yang solid dan bertanggungjawaban yang sejalan dengan demokrasi dan pasar yang efisien, penghindaran salah alokasi dana dan pencegahan korupsi secara politik dan administrasi, menjalankan disiplin anggaran serta penciptaan kerangka kerja politik dan hukum bagi tumbuhnya akuntabilitas.

Pemerintah desa ke empat desa yang dijadikan lokasi peneliian, sangat banyak menggunakan anggaran untuk program pembangunan desa, menurut pemerintah desa hal ini dilakukan karena dengan pembangunan yang baik akan menciptakan kemajuan bagi desa dan tidak kalah pentingnya yaitu sikap percaya yang diberikan masyarakat kepada pemerintah desa ataupun sebaliknya, maka dari itu seharusnya pemerintah desa menjalankan perannya secara benar Journal of Governance and Local Politics (JGLP) ISSN (online): 2684-9992, Vol: 1, Nomor: 1, Mei 2019 
terutama dalam hal pengawasan anggaran desa. Seperti yang sudah penulis jelaskan dalam undang-undang dan peraturan pemerintah lainnya, pemerintah desa dalam proses pengawasan anggaran juga harus mengabarkan atau mensosialisasikan informasi kepada seluruh masyarakat desa, tidak hanya diinformasikan kepada pejabat yang lebih tinggi saja (Bupati, DPRD). Jadi pemerintah desa harus umumkan kepada masyarakat informasi keuangan desa yang ada secara detail apa benar anggaran digunakan untuk pembangunan desa.

Sulistiyani berpendapat bahwa akuntabilitas mempunyai dua kunci dalam penyelenggaraan pemerintahan baik pusat, daerah maupun ranah lokal (desa), dinyatakan juga bahwa dalam akuntabilitas terkandung kewajiban untuk menyajikan dan melaporkan segala kegiatan terutama dalam bidang administrasi keuangan kepada pihak yang lebih tinggi dan masyarakat. Akuntabilitas dapat dilaksanakan dengan memberikan akses kepada semua pihak yang berkepentingan, bertanya atau menggugat pertanggugnjawaban para pengambil keputusan dan pelaksana baik ditingkat program, daerah dan masyarakat. Dalam hal ini maka semua kegiatan yang barkaitan dengan pengelolaan keuangan desa harus dapat diakses oleh semua unsur yang berkepentingan terutama masyarakat desa.

Pemerintah desa harus sangat berhati-hati dengan dana yang diterima oleh desa, dengan anggaran yang banyak ini bisa terjadi kesalahgunaan yang dilakukan oleh pejabat pemerintah desa. Anggaran yang digunakan seharusnya selalu dibuat laporan pertanggugngjawaban yang baik agar mudah diawasi oleh pemerintah daerah ataupun masyarakat desa itu sendiri.

Seperti yang dilhat pada tabel 3 di atas bawah anggaran yang diterima oleh keempat desa ini tidaklah sedikit yaitu (1) Desa Benete Kecamatan Maluk saja mendapatkan anggaran yang mencapai Rp. 1.274.140.574.00 sebelum anggaran perubahan dan Rp. 1.536.579.685.00 setelah anggaran perubahan, (2) Desa Maluk Kecamatan Maluk mendapatan anggaran yang mencapai Rp. Journal of Governance and Local Politics (JGLP) ISSN (online): 2684-9992, Vol: 1, Nomor: 1, Mei 2019 
1.372.612.452.00 tahun anggaran 2016, (3) Desa Sekongkang Bawah Kecamatan Sekongkang yang mendapatan anggaran yang mencapai Rp. 1.200.941.042.00 sebelum anggaran perubahan dan setelah anggaran perubahan mencapai angka Rp. 1.329.909.372.00, (4) Desa Sekongkang Atas Kecamatan Sekongkang yang memperoleh anggaran mencapai Rp. 1.595.752.383.00 dan berubah setelah adanya perubahan anggaran yang mencapai Rp. 1.622.712.383.00. Dengan banyaknya anggaran yang diterima oleh pemerintah desa diatas, seharusnya pemerintah desa bisa melakukan pengawasan sumber pendapatan dan pengawasan belanja yang dilakukan oleh desa agar pengunaan anggaran bisa dipertanggungjawabkan dengan baik oleh pemerintah desa.

Hal ini terlihat jelas oleh penulis bahwa masih belum baiknya penganggaraan yang dilakukan oleh desa. Banyaknya anggaran yang tidak tepat pada porsinya, hal ini dikarenakan tidak siapnya perangkat desa dalam penyusunan anggaran belanja desa yang berdampak pada banyaknya anggraan yang digunakan tidak pada posnya oleh pemerintah desa. Seperti yang kita ketahui bahwa penyusunan APBDes yang dilakukan oleh pihak desa sudah dilakukan dengan sekuat tenaganya, hanya masih kurang. Desa selalu melakukan musyawarah desa bakal sampai ke dusun-dusun. Hal ini diharapkan bisa memuat semua pendapat yang diberikan oleh masyarakat desa tentang pengelolaan keuangan desa, baik itu pendapatan desa maupun belanja desa. Untuk melihat siklus akuntabilitas yang baik seharusnya pemerintah desa melakukan beberapa hal untuk meningkatkan kinerja pemerintahan desa dalam pengelolaan keuangan desa kedepannya.

Sistem akuntabilitas kinerja merupakan tatanan, instrumen, metode pertanggungjawaban yang pada dasarnya meliputi tatanan penyusunan rencana, pengukuran, dan pelaporan atau evaluasi yang dilakukan oleh pemerintah desa yang membentuk siklus akuntabilitas kinerja yang tidak terputus dan terpadu yang merupakan infrastrukur bagi proses pemenuhan kewajiban penyelenggaran Journal of Governance and Local Politics (JGLP) ISSN (online): 2684-9992, Vol: 1, Nomor: 1, Mei 2019 
dari pemerintah desa. Berikut ini bagan siklus akuntabilitas kinerja menurut Sjahruddin sebagai berikut:

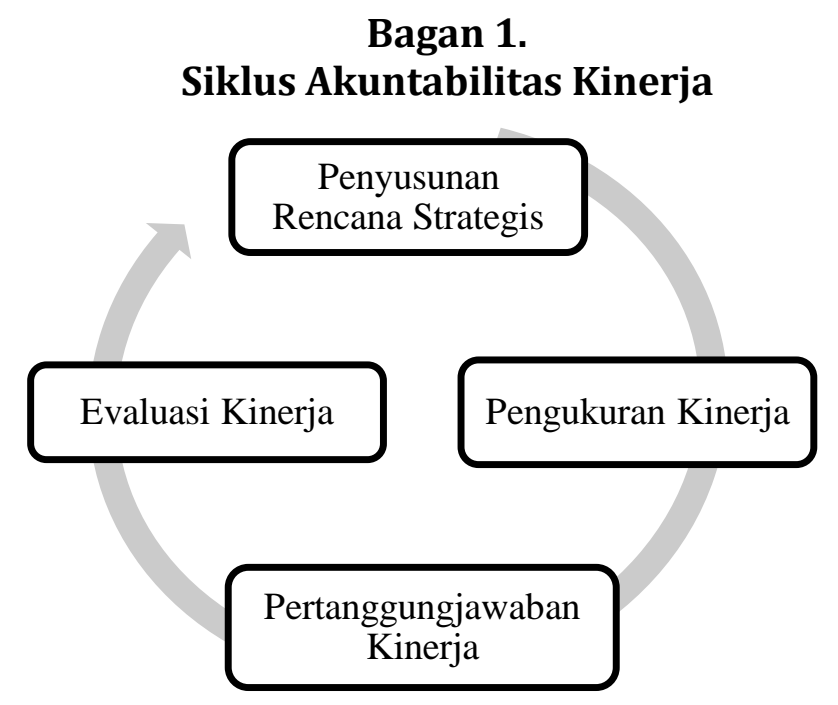

Bagan di atas bisa membuktikan bahwa siklus akuntabilitas kinerja tersebut belum sepenuhnya dilakukan oleh keempat desa lokasi penelitian, hal ini dikarenakan kurangnya pengatahuan perangkat desa dalam proses pengelolaan keuangan desa yang baik, baik itu dari unsur penyusunan rencana anggaran yang dibutuhkan lalu pengukuran kinerja pelaksana yang baik guna menjalankan pelaksanaan sesuai dengan yang sudah direncankan maupun pertanggungjawaban atau evaluasi yang benar-benar dilakukan dengan standar yang sudah diamanahkan oleh undang-undang.

Sebagai sebuah program atau kegiatan bersiklus tahunan, pengelolaan keuangan dilaksanakan setiap tahun berjalan. Oleh karena hal itu, proses pelaksanaan pengeloaan keuangan, mulai dari perencanaan, pelaksanaan sampai pada pertanggungjawaban atau evaluasi juga dilakukan setiap tahun. Semua pengeluaran dan penggunaan dari keuangan ini dibukukan sedimikian rupa oleh perangkat desa walaupun ada beberapa format pembukuan yang tidak 
mengikuti petunjuk pembukuan dikarenakan belum fasenya perangkat desa dalam hal ini.

Masalah lainnya yang sering dihadapi oleh pihak desa ialah pemberian informasi secara terbuka terhadap kritik yang diberikan oleh masyarakat untuk melakukan perbaikan pembangunan. Oleh karena itu perlu dikembangkan manajemen interaksi antar semua stakeholders pembangunan dengan tetap berpegang pada prinsip partisipatif, responsive, transparan, dan akuntabel mulai dari tahap perencanaan, pelaksanaan, dan pertanggungjawaban sehingga hasil dari tingkat partisipasi tersebut cukup membangunan. Namun demikian penerapan prinsip-prinsip tersebut harus dilakukan evaluasi dari waktu ke waktu untuk mencapai kesempurnaan tujuan program keuangan desa secara umum di empat desa tersebut (Desa Benete, Desa Maluk, Desa Sekongkang Bawah, Desa Sekongkang Atas) dari hasil penelitian yang dilakukan oleh penulis, dapat dirangkum bahwa kebijakan yang diambil keempat desa dalam proses pengelolaan keuangan desa sudah berdasarkan pada prinsip-prinsip tanggugjawab, walaupun masih belum sepenuhnya sesuai dengan ketentuan yang ada.

Dengan demikian perlu dilakukan penyempurnaan secara berkelanjutan dengan tetap menyesuiakan situasi dan kondisi serta perkembangan peraturan perundang-undang yang berlaku. Sedangkan untuk beberapa hal lain ada Desa Maluk dan Sekongkang Bawah masih belum terlalu baik dalam pengelolaan keuangan desa antara lain (1) kurang efektifnya sistem pembinaan dari pemerintah kecamatan dan pemerintah daerah terhadap pengelolaan keuangan desa (APBDes). (2) rendahnya kompetensi maupun tingkat pendidikan aparat pemerintah desa yang merupakan ujung tombak pelaksanaan keuangan desa (APBDes).

Tabel 4.

Indeks Tentang Pengelolan Keuangan Desa Pada 4 (Empat) Desa 


\begin{tabular}{|c|c|c|c|c|c|c|}
\hline \multirow{2}{*}{ Desa } & \multicolumn{3}{|c|}{ Nilai Indeks } & \multicolumn{3}{c|}{ Keterangan Indeks } \\
\cline { 2 - 7 } & $\mathbf{1}$ & $\mathbf{2}$ & $\mathbf{3}$ & $\mathbf{1}$ & $\mathbf{2}$ & $\mathbf{3}$ \\
\hline Desa Benete & 2.52 & 2.19 & 2.60 & Kurang & Kurang & Kurang \\
\hline $\begin{array}{c}\text { Desa Maluk } \\
\text { Desa Sekongkang } \\
\text { Bawah }\end{array}$ & 2.93 & 2.31 & 2.69 & Cukup & Kurang & Cukup \\
\hline $\begin{array}{c}\text { Desa Sekongkang } \\
\text { Atas }\end{array}$ & 2.28 & 2.45 & 2.72 & Cukup & Kurang & Cukup \\
\hline
\end{tabular}

Sumber: diolah penulis

\section{Tingkat Partisipasi Masyarakat}

Partisispasi masyarakat ialah keikutusertaan masyarakat dalam proses pengidentifikasian masalah dan potensi yang ada di masyarakat desa, agar pemilihan dan pengambilan keputusan tentang masalah yang dihadapi masyarakat desa bisa diambil dengan solusi yang terbaik untuk menangani masalah, pelaksanaan upaya mengatasi masalah, dan keterlibatan masyarakat dalam proses mengevaluasi perubaan yang tarjadi di tengah masyarakat.

Untuk mengetahui pendapat masyarakat tentang upaya aparatur pemerintah desa dalam proses pengelolaan keuangan desa bisa langsung dilihat pada tabel dibawah ini yang memperlihatkan bahwa 100 responden yang berada pada Desa Benete, Desa Maluk kecamatan Maluk dan Desa Sekongkang Bawah, Desa Sekongkang Atas Kecamatan Sekongkang Kabupaten Sumbawa Barat dengan rincian sebagai berikut:

Pada tabel 4 hasil indeks tentang pengelolaan keuangan desa penomoran 1, 2 dan 3 masing-masing perencanaan, pelaksanaan dan pertanggunjawaban. Bisa dilihat bahwa (1) Desa Benete Kecamatan Maluk nilai indeks pada Perencanaan 2.52 (Kurang). Pelaksanaan 2.19 (Kurang) dan pertanggngjawaban 2.60 (Kurang), (2) Desa Maluk Kecamatan Maluk nilai indeks pada perencanaan mencapai 2.93 (Cukup). Pelaksanaan 2.31 (Kurang) lalu pertanggungjawaban 2.69 (Cukup), (3) Desa Sekongkang Bawah Kecamatan Sekongkang dengan nilai 
indeks perencanaan 2.92 (Cukup), pelaksanaan 2.45 ( Kurang) dan pertanggungjawaban 2.72 (Cukup), (4) Desa Sekongkang Atas Kecamatan Sekongkang dengan nilai indeks perencanaan sebesar 2.28 (Kurang), pelaksanaan sebesar 2.24 (Kurang) dan pertanggungjawaban 3.05 (Cukup).

Dari hasil indeks (kuesioner) yang disebarkan ke 4 (empat) desa pada Kecamatan Maluk dan Kecamatan Sekongkang, penulis dapat menjelaskan bahwa akuntabilitas terkait pertanggungjawaban laporan keuangan desa baru beberapa desa yang telah melakukan pertanggungjawaban laporan keuangan desa secara baik. Artinya beberapa desa tersebut telah melakukan laporan keuangan sesuai dengan undang-undang atau peraturan yang berlaku.

Akuntabilitas yang baik harus dilakukan keterbukaan prosedur/tata cara, pejabat yang bertanggungjawab, waktu penyelesaian dan rincian biaya harus benar-benar terbuka untuk masyarakat agar mudah diketahui oleh masyarakat baik diminta maupun tidak diminta. Pemerintah desa harus melakukan pelayanan dengan tidak membedakan golongan atau status masyarakat yang akan dilayani. Hal tersebut terjadi karena ke empat desa tersebut terdapat banyak golongan dan suku yang berbeda. Jangan sampai dengan adanya membedaan akan membuat masyarakat tidak percaya kepada pemerintah desa.

Tata kelola pemerintahan yang baik merupakan salah satu tuntunan masyarakat yang harus dipenuhi. Salah satu pilar tata kelola tersebut ialah akuntabilitas. Sebeni dan Ghozali menyatakan bahwa akuntabilitas atau pertanggungjawaban merupakan suatu bentuk keharusan seseorang untuk menjamin bahwa tugas dan kewajiban yang diembannya sudah dikalsanakan sesuai ketentuan yang berlaku. Data diatas seolah-olah dibantah oleh pemerintah desa yang berpendapat bahwa persoalan pertanggungjawaban keuangan desa pihak pemerintah desa sudah melakukannya dengan sangat baik, itu bisa dilihat dari hasil laporan pertanggungjawban yang dibuat oleh pejabat desa, pemerintah desa juga selalu menudang masyarakat untuk ikut serta dalam Journal of Governance and Local Politics (JGLP) ISSN (online): 2684-9992, Vol: 1, Nomor: 1, Mei 2019 
proses pertanggungjawaban atau LPJ. Hal ini sangat penting dilakukan dikarena masyarakat juga harus tahu terkait laporan tersebut. Jadi tidak hanya pemerintah yang lebih tinggi saja yang tahu (pemerintah daerah). Apa yang disampaikan pihak pemerintah desa di atas sangat bertantangan dengan apa yang dirasakan oleh masyarakat desanya sendiri, hal ini dikarenkan adanya perbedaan antara pemerintah desa dan masyarakat desa. Persoalan ini apabila tidak segara diperbaiki akan menjadi masalah yang besar dan akan memperlambat pembangunan desa.

\section{KESIMPULAN}

Berdasarkan hasil penelitian tantang akuntabilitas pemerintah desa dalam pengelolaan keuangan desa pada empat desa di Kecamatan Maluk dan Kecamatan Sekongkang Kabupaten Sumbawa Barat dapat ditarik kesimpulan bahwa dari perencanaann pelaksanaan dan pertanggungjawaban sudah berjalan walaupun masih ada kekurangan dalam prosesnya atau masih ada kelemahan.

Perencanaan program keuangan desa secara bertahap telah melaksanakan prinsip-prinsip akuntabilitas dengan cukup baik. Hal ini dibuktikan dengan adanya musyawarah wujud dari partisipasi masyarakat desa. Didukung dengan adanya komitmen yang kuat untuk selalu ikutserta dalam proses perencanaan program desa. Pelaksanaan program telah menerapkan prinsip-prinsip akuntabilitas berupa komitmen sistem aturan, tujuan sasaran, visi-misi, hasil, serta sasaran yang sudah dipastikan kedepannya oleh pemerintah desa. walaupun penerapan prinsip akuntabilitas pada tahap ini masih terbatas pada pertanggungjawaban administratif, sedangkan secara teknis masih belum sepenuhnya sempurna.

Pertanggungjawaban atau pengawasan yang dilakukan oleh Badan Perwusyawaratan Desa (BPD) dalam pengelolaan keuangan desa secara administatif sudah cukup baik. Terbukti dari surat pertanggungjawaban (SPJ) 
yang dibuat dalam II tahap yang menjadi aturan dalam peraturan Bupati Sumbawa Barat Nomor 8 Tahun 2016. Namun dalam hal pertanggungjawaban secara teknis dalam beberapa program masih terjadi kendala. Kendala utama karena rendahnya partisipasi masyarkat untuk ikut dalam proses pertanggungjawaban. Sehingga masih memerlukan perbaikikan secara teknis dalam pengelolaan keuangan desa tahun berikutnya.

\section{REFRENSI}

Dwiyanto, Agus. (2014). Mewujudkan Good Governance Melalui Pelayanan Publik. Yogyakarta: Gadjah Mada University Press.

Faridah, f. (2016). Transparansi dan akuntabilitas pemerintah desa dalam pengelolaan anggaran pendapatan dan belanja desa (apbdes). Jurnal ilmu \& riset akuntansi, 4(5).

Nurtabzila L. (2013) Standar akuntansi Pemerintahan dalam Mewujudkan Akuntabilitas dan Transparansi Pengelolaan Keuangan Daerah: Jurnal Kebijakan dan Administrasi Publik JKAP Vol 17 No 1 Mei 2013.

Lestari, a. K. D., atmadja, a. T., se, a., adiputra, i. M. P., se, s., \& si, m. (2014). Membedah akuntabilitas praktik pengelolaan keuangan desa pakraman kubutambahan, kecamatan kubutambahan, kabupaten buleleng, provinsi bali (sebuah studi interpretif pada organisasi publik non pemerintahan)

John T. Ishiyama dan Marijke breuning. (2013). Ilmu Politik dalam Paradigma abad ke 21. Jakarta: Kencana Prenada media group.

Kumorotomo Wahyudi. (2013). Akuntabilitas Birokrasi Publik Sketsa Pada Masa Transisi. Yogyakarta: Pustaka Pelajar.

Mardiasmo. 2005. Akuntansi sektor publik. Yogyakarta: Andi

Sugiyono. (2013). Metode Penelitian Kuantitatif Kualitatif dan R\&D. Bandung: Alfabeta. 
(2016). Metode Penelitian Kombinasi (Mixed Methods). Bandung: Alfabeta.

Laporan Realisasi Pelaksanaan Anggaran Pendapatan dan Belanja Desa Sekongkang Atas Tahun Anggaran 2016.

Peraturan Desa Benete Kecamatan Maluk Kabupaten Sumbawa Barat Nomor 04 Tahun 2016 Tentang Perubahan Peraturan Desa Nomor 04 Tahun 2016 Tentang Anggaran Pendapatan Dan Belanja (APBDes) Tahun Anggaran 2016.

Peraturan Desa Maluk Kecamatan Maluk Kabupaten Sumbawa Barat Nomor 01 Tahun 2016 Tentang Anggaran Pendapatan Belanja Desa Tahun Anggaran 2016.

Peraturan Desa Sekongkang Bawah Kecamatan Sekongkang Kabupaten Sumbawa Barat Nomor 04 Tahun 2016 Tentang Perubahan Atas Perubahan Desa Nomor 01 Tahun 2016 Tentang Anggaran pendapatan dan Belanja Desa Tahun Anggaran 2016.

Surat Pertanggungjawaban (SPJ) Realisasi Pelaksanaan Dana Desa Tahun Anggaran 2016.

Surat Pertanggungjawaban (SPJ) Realisasi Pelaksanaan Alokasi Dana Desa Tahun Anggaran 2016

Undang-Undang Republik Indonesia Nomor 6 Tahun 2014 Tentang Desa. 